\title{
Production and Some Properties of Rennin-like Milk-clotting Enzyme from Penicillium citrinum
}

\author{
By A. F. ABDEL-FATTAH, SOUHAIR S. MABROUK \\ AND NADIA M. EL-HAWWARY \\ Laboratory of Microbiological Chemistry, National Research Centre, \\ Dokki, Cairo, Egypt
}

(Accepted for publication 12 October 197I)

\begin{abstract}
SUMMARY
The production of a rennin-like milk-clotting enzyme by Penicillium citrinum 805 was investigated. Corn-steep water was the best medium for the production of the enzyme. Dephytinization of corn-steep water lowered production of the enzyme. The extent of mycelial sporulation was correlated with the milk-clotting activity. Precipitation with ammonium sulphate and ethanol was unsuitable, but acetone produced active fractions. The enzyme action was optimal at $60^{\circ}$ and at $\mathrm{pH} 6 \cdot 0$ while the stability of the enzyme was maximal at $\mathrm{pH} 5 \cdot 37$. The enzyme exhibited feeble proteolytic activity.
\end{abstract}

\section{INTRODUCTION}

All proteolytic enzymes can clot milk, but rennin is the main milk-clotting enzyme. A rennin enzyme or rennin substitute, suitable for cheese making, is characterized by a high milkclotting activity and low proteolytic action. These enzymes occur in animal tissues and higher plants as well as in micro-organisms. Although much is known about enzymes of animal and plant origins, little is known about microbial milk-clotting enzymes. Attention has therefore recently focused on the production of milk-clotting enzymes from microbial sources for use as rennin substitutes (Srinivasan, Anantharamiah, Ananthakrishnan \& Iya, I962a; Srinivasan et al. 1964; Veselov, Tipograph \& Petina, I965; Iwasaki, Tamura \& Arima, 1967; Osman, Abdel-Fattah, Abdel-Samie \& Mabrouk, 1969; Paleva, 1969; Kawai, 1970; Kawai \& Mukai, 1970). Successful attempts to use microbial milk-clotting enzymes have been made by some investigators (Srinivasan, Anantharamiah, Keshavamurthy, Ananthakrishnan \& Iya, I962 b; Toshihiko \& Shuji, 1969) and calcium phytate was reported by Srinivasan et al. (1964) to stimulate the production of milk-clotting enzymes of some Bacillus isolates and also of the proteases of some bacteria (Tsuychihira, 1954).

The present work was undertaken to study the production of milk-clotting enzyme by Penicillium citrinum in different culture media including dephytinized corn-steep water, its partial purification, and some of its properties. These studies may throw some light on the value of the fungal enzyme preparation as a rennin-like enzyme.

\section{METHODS}

Organism. Penicillium citrinum 805 (NRRL) was used in this work.

Culture media. Thirteen media were used and are listed in Table I.

Dephytinization of corn-steep water. This was done according to the method of Zelinka, Hudec \& Pelcova (I96I). A corn-steep water of $2 \%$ (w/v) was used. 
Cultivation. Transfers were made from the subcultures to Dox's agar plates which were then incubated at $30^{\circ}$ for seven days. Cultivation was in $250 \mathrm{ml}$ flat-bottomed flasks, each containing $50 \mathrm{ml}$ of sterile medium. Four discs $(0.5 \mathrm{~cm}$ diam.) were cut from the seven-day-old culture plates and used for inoculating each flask. After incubation for seven days at $30^{\circ}$, the culture medium was filtered and its volume adjusted to $50 \mathrm{ml}$.

Measurement of milk-clotting activity. This was done by the method of Berridge (1952); unless otherwise specified, $2.5 \mathrm{ml}$ of the enzyme sample were incubated with $10 \mathrm{ml}$ reconstituted skim-milk ( $12 \mathrm{~g}$ dry skim-milk/ $/ 00 \mathrm{ml} \mathrm{O.0I} \mathrm{M}-\mathrm{CaCl}_{2}$ ) at $40^{\circ}$ and the clotting time recorded. One unit of enzyme activity was taken to be that which clotted ro $\mathrm{ml}$ milk in Io min.

Estimation of protein content. This was done by the method of Lowry, Rosebrough, Farr \& Randall (I95I).

Examination of gelatinase activity. This was done according to the method of Bergkvist (I963) for proteases of Aspergillus oryzae by estimating the decrease in the relative viscosity of a $5 \%(\mathrm{w} / \mathrm{v})$ buffered gelatin solution (citrate + phosphate buffers of different $\mathrm{pH}$ values) containing the enzyme.

Examination of caseinase activity. This was done according to the method of Bergkvist (1963) by determining the rate of hydrolysis of $\mathrm{I} \cdot 5 \%(\mathrm{w} / \mathrm{v})$ casein (isoelectric casein) in phosphate buffer (ph 7.4) containing the enzyme, after incubation for $30 \mathrm{~min}$ at $37^{\circ}$. The increase in extinction $(280 \mathrm{~nm})$ of trichloroacetic acid filtrate was used as a measure of proteolytic activity.

Precipitation of milk-clotting enzyme. This was achieved with ammonium sulphate, ethanol or acetone using the culture filtrate obtained by culturing the organism on the cornsteep water $(2 \%, w / v)+$ lactose $(2 \%, w / v)$ medium. With ammonium sulphate, centrifugation was at II,000 rev./min and with ethanol or acetone at $3000 \mathrm{rev} . / \mathrm{min}$. Suspensions of ammonium sulphate precipitates and their supernatant fluids were dialysed against distilled water while each of the other precipitates was resuspended in a known volume of water.

Properties of milk-clotting enzyme. These were studied in the precipitate obtained by treating the culture filtrate with 2 vol. ice-cold acetone.

\section{RESULTS AND DISCUSSION}

Production of milk-clotting enzyme. Corn-steep water proved to be the best medium for the production of extracellular milk-clotting enzyme (Table I). Considerable activity was also achieved by supplementing corn-steep water with lactose. Dephytinization of corn-steep water resulted in almost complete absence of milk-clotting activity. This may have been partially due to the removal of phytic acid (or related compound) from the corn-steep water which is known to contain this compound (Graefe, 1952; Abdel-Akher \& Michalinos, 1962). The recovery of milk-clotting activity by the addition of inositol + potassium dihydrogen phosphate to the dephytinized corn-steep water may support this view. This result is in agreement with that of Srinivasan et al. (1964) who found that calcium phytate stimulated the production of milk-clotting enzyme in bacteria. The addition of either inositol or casaminoacids had an adverse effect on the production of milk-clotting enzyme. Skim-milk was unsuitable for its production.

When the culture filtrate showed weak or no milk-clotting activity, the corresponding mycelia were partially or completely non-sporing. The association of milk-clotting activity with spore formation was also observed by Osman et al. (1969).

Partial purification of the milk-clotting enzyme. Ammonium sulphate was unsuitable for 
salting out active fractions of the milk-clotting enzyme (Table 2). Although all precipitates possessed weak activities, two were more active. These had been salted out with ammonium sulphate of 30 and $100 \%$ saturations. Their activities represented about 27 and $16.88 \%$, respectively, of that of the culture filtrate.

Ethyl alcohol was also unsuitable and gave precipitates with no activity with the exception of two which were obtained by treating the culture filtrate with 2 and 8 vol. of alcohol (Table 2). However, both possessed only weak milk-clotting activity.

Acetone gave the most active precipitates, and 2 vol. yielded a precipitate with even higher milk-clotting activity than the culture filtrate (Table 2). Gradual loss of enzyme activity occurred on precipitation with higher acetone concentrations.

Properties of the milk-clotting enzyme. The milk-clotting activity of the enzyme was maximal at $60^{\circ}$ but nearly identical activity was achieved at $55^{\circ}$. This result is similar to those found for other microbial milk-clotting enzymes (Osman et al. 1969; Kawai \& Mukai, 1970; Arnold, Stefan \& Wanda, 1970). The enzyme showed maximal milk-clotting activity at

\section{Table I. Production of milk-clotting enzyme by Penicillium citrinum 805 in different culture media}

\section{Medium}

CSW $(2 \%, w / v)$

CSW $(2 \%, w / v)+$ lactose $(2 \%, w / v)$

CSW $(2 \%, w / v)+$ glucose $(2 \%, w / v)$

CSW $(2 \%, w / v)+$ lactose $(2 \%, w / v)+$ inositol ( $0.1 \%, w / v)$

CSW $(2 \%, w / v)+$ lactose $(2 \%, w / v)+$ inositol $(0 \cdot 2 \%, w / v)$

$\operatorname{CSW}(2 \%, \mathrm{w} / \mathrm{v})+$ lactose $(2 \%, \mathrm{w} / \mathrm{v})+\mathrm{KH}_{2} \mathrm{PO}_{4}$ $(0 \cdot I \%, \mathrm{w} / \mathrm{v})$

$\operatorname{CSW}(2 \%, \mathrm{w} / \mathrm{v})+$ lactose $(2 \%, \mathrm{w} / \mathrm{v})+$ casaminoacids $(0 \cdot I \%, w / v)$

Dephytinized CSW

Dephytinized CSW + lactose $(2 \%$ w/v)

Dephytinized CSW + lactose $(2 \%, w / v)+$ inositol $(0 \cdot 1 \%, \mathrm{w} / \mathrm{v})+\mathrm{KH}_{2} \mathrm{PO}_{4}(0 \cdot 1 \%$, w/v)

Skim-milk solution $(10 \%$, w/v)

Skim-milk solution $(10 \%, w / v)+$ glucose $(1 \%, w / v)$

Skim-milk solution $(10 \%, \mathrm{w} / \mathrm{v})+$ glucose $(\mathrm{I} \%, \mathrm{w} / \mathrm{v})+\mathrm{CaCl}_{2}(0.005 \mathrm{M})$
Milk-clotting activity (units/mg protein)

0.3172
0.2670
0.2380
0.2380
0.1070
0.2480
0.1490
0.0019
$\mathrm{NC}$
0.1728
$\mathrm{NC}$
0.0011
0.0012

CSW $=$ corn-steep water $; \mathrm{NC}=$ no clotting. See Methods for definition of unit of milk-clotting activity.

Table 2. Milk-clotting activity of ammonium sulphate, ethanol and acetone precipitates of Penicillium citrinum enzyme preparations

Milk-clotting activity (unit/mg protein) (I) at various ammonium sulphate saturations (\%) and

(2) in various proportions $(\mathrm{v} / \mathrm{v})$ of culture filtrate + acetone (a) and ethanol (e).

(I) ppt

(2) supt ppt (a) ppt (e)
30

$0 \cdot 173$

$0 \cdot 168$

I + I

$\mathrm{NC}$

$\mathrm{NC}$
50

0.084

0.045

I +2

0.67

0.24
66

0.079

0.072

$\mathrm{I}+4$

0.43

NC

$\begin{array}{ll}80 & 100 \\ 0.082 & 0.108 \\ 0.103 & 0.083 \\ \mathrm{I}+6 & \mathrm{I}+8 \\ 0.24 & 0.24 \\ \mathrm{NC} & 0.05\end{array}$

Activity of original culture filtrate was $0.64 \mathrm{unit} / \mathrm{mg}$ protein. $\mathrm{ppt}=$ precipitate; supt $=$ supernatant $; \mathrm{NC}=$ no clotting. 
pH 6.0; $\mathrm{I} \cdot 45 \mathrm{mg}$ enzyme protein in $2.5 \mathrm{ml}$ was sufficient to clot $\mathrm{I} \cdot 2 \mathrm{~g}$ reconstituted skimmilk in $\mathrm{IO} \mathrm{ml}$ within $\mathrm{I} 48 \mathrm{~s}$ at $\mathrm{pH} 6.0$ and $60^{\circ}$. Thus the fungal enzyme quickly clotted about 827 times its own weight of skim milk. In this respect, the milk-clotting enzyme preparation of Penicillium citrinum was superior to the bacterial rennin which was reported by Srinivasan, Anantharamiah \& Lakashmi (1959) to clot the same amount of milk within $20 \mathrm{~min}$.

A substrate concentration (reconstituted skim-milk) higher than $12 \mathrm{~g} / \mathrm{I} 00 \mathrm{ml}$ was a limiting factor for milk-clotting activity. The addition of proportional amounts of calcium chloride to skim-milk suspensions enhanced the clotting stage of enzyme action but the activity was not completely recovered, perhaps because of the resulting unfavourable reaction medium or the high substrate/enzyme ratio or both.

Although the milk-clotting activity was maximal at $60^{\circ}$ (pH 6.0), it was destroyed when heated for ro min at $55^{\circ}$ and $\mathrm{pH} 3.42$ in the absence of substrate. At $40^{\circ}$ the milk-clotting enzyme was most stable at $\mathrm{pH} 5 \cdot 37$ (Table 3).

The milk-clotting enzyme had a low proteolytic activity. After incubation with casein, the increase in optical density of the trichloroacetic acid filtrate was only 0.018 , indicating low proteolytic action (Bergkvist, 1963). Also, the enzyme acted feebly on gelatin solutions as compared with fungal proteolytic enzymes (Bergkvist, 1963). In a reaction lasting for 5 min the maximum reduction in relative viscosity of gelatin solution, $\mathrm{pH}_{4} \cdot 0$, was $5 \cdot 2 \%$. At lower and higher $\mathrm{pH}$ values, reduction in viscosity did not exceed $3.4 \%$. When the time of reaction at $\mathrm{pH} 4.0$ was extended to $90 \mathrm{~min}$, there was still only $17.4 \%$ reduction in viscosity.

The results show that the milk-clotting enzyme preparation of Penicillium citrinum possessed high milk-clotting activity and low proteolytic action, and accordingly may be considered as a rennin-like enzyme.

Table 3. The $p H$ stability at $40^{\circ}$ of the partially purified milk-clotting enzyme preparation from Penicillium citrinum

$\begin{array}{cccccc}\begin{array}{c}\text { pH of } \\ \text { enzyme } \\ \text { solution }\end{array} & \begin{array}{c}\multicolumn{5}{c}{\begin{array}{c}\text { Milk-clotting activity (unit/mg protein) at different } \\ \text { times of incubation of enzyme solution* (min) }\end{array}} \\ 3.42\end{array} 6^{6.27} & 30 & 60 & 120 & 180 \\ 4.05 & 6.20 & 5.25 & 4.28 & 2.85 & 1.50 \\ 4.63 & 6.69 & 5.10 & 4.80 & 3.61 & 3.06 \\ 4.99 & 7.38 & 6.44 & 6.29 & 5.47 & 4.69 \\ 5.37 & 8.36 & 7.06 & 6.46 & 5.71 & 5.15 \\ 5.89 & 7.74 & 7.67 & 6.5 \mathrm{I} & 5.84 & 4.93 \\ & 7.71 & 6.83 & 4.61 & 2.63\end{array}$

* Before incubation with milk, the pH of the enzyme solution was readjusted to 4.05 (acetate buffer, $0.02 \mathrm{M}$ ).

\section{REFERENCES}

Abdel-Axher, M. \& Michalinos, A. N. (1962). Separation of the corn-steeping water proteins by precipitation. Die Stärke 14, I24-128.

ARNold, R., STEFAn, P. \& WANDA, K. (1970). Characteristics of milk-coagulating proteases obtained from Byssochlamys fulva and Endothia parasitica. Milchwissenschaft 25, 146-150.

BergKvist, R. (1963). The proteolytic enzymes of Aspergillus oryzae. I. Methods for the estimation and isolation of the proteolytic enzymes. Acta chemica scandinavica 17, I52 I-I540.

BERRIDGE, N. J. (1952). Some observations on the determination of the activity of rennet. Analyst, London 77, $57-62$.

GrAEFE, G. (1952). Meso-inositol from corn-steep liquor. Die Stärke 4, 275-282.

IwASAKI, S., TAMURA, G. \& ARIMA, K. (1967). Milk-clotting enzyme from micro-organisms. II. The enzyme production and the properties of crude enzyme. Agricultural and Biological Chemistry 3I, 546-55I. 
KaWAI, M. (1970). Studies on milk-clotting enzymes produced by Basidiomycetes. II. Some properties of Basidiomycete milk-clotting enzymes. Agricultural and Biological Chemistry 34, 164-169.

KawaI, M. \& MukaI, N. (1970). Studies on milk-clotting enzymes produced by Basidiomycetes. I. Screening tests of Basidiomycetes for the production of milk-clotting enzymes. Agricultural and Biological Chemistry 34, 159-163.

Lowry, O. H., Rosebrough, N. J., Farr, A. L. \& Randall, R. J. (I95I). Protein measurement with the Folin phenol reagent. Journal of Biological Chemistry I93, 265-275.

Osman, H. G., Abdel-Fattah, A. F., Abdel-Samie, M. \& Mabrouk, S. S. (1969). Production of a milkclotting enzyme preparation by Aspergillus niger and the effect of various factors on its activity. Journal of General Microbiology 59, I25-I 29.

PaleVa, N. S. (1969). Rennin production by Aspergillus. Mikrobiologiya 38, 1002-1005.

Srinivasan, R. A., Anantharamiah, S. N., Ananthakrishnan, C. P. \& IYa, K. K. (I962a). Studies on milk-clotting bacterial enzyme for cheese making. I. Some factors influencing the elaboration of the enzyme by bacteria. XVI International Dairy Congress, Section IV I, 40I-409.

Srinivasan, R. A., Anantharamiah, S. N., Keshavamurthy, N., Ananthakrishnan, C. P. \& IYa, K. K. $(1962 b)$. Studies on milk-clotting bacterial enzyme for cheese making. Il. Preparation of Cheddar cheese by using bacterial enzymes. XVI International Dairy Congress, Section IV I, 506-512.

Srinivasan, R. A., Anantharamiah, S. N. \& Lakashmi, N. V. (I959). Studies on the manufacture of bacterial rennin as substitute for calf rennin. Indian Institute of Science Golden Jubilee Symposia, p. 22.

Srinivasan, R. A., Iyengar, M. K. K., Babbar, I. J., Chakravorty, S. C., Dudani, A. T. \& Iya, K. K. (1964). Milk-clotting enzymes from micro-organisms. Applied Microbiology I2, 475-478.

ToshIHIxo, K. \& ShUנI, T. (1969). Microbial rennet. IV. Experimental cheese making with crystallized microbial rennet. Yukijirushi Nyugyo Gijutsu Kenkyujo Hokoku, no. 71, II-24. Cited from Chemical Abstracts (1970) 73, 2783.

TsuYCHIHIRA, K. (I954). Stimulation of protease formation by rice bran. Seikagaku 26, 436-437. Cited from Srinivasan et al. (1964).

Veselov, I. Ya., Tipograph, D. Ya. \& Petina, T. A. (I965). Aspergillus candidus as a producer of rennin. Prikladnaya Biokhimija Mikrobiologiya I, 52-56.

Zelinka, J., Hudec, M. \& Pelcova, L. (1961). Influence of dephytinization of corn broth on the biosynthesis of penicillin. Biologia, Bratislava $\mathbf{1 6}, 53-56$. 